\title{
Analysis of Replicating Mitochondrial DNA by In Organello Labeling and Two- Dimensional Agarose Gel Electrophoresis
}

\author{
lan J. Holt, Lawrence Kazak, Aurelio Reyes, and Stuart R. Wood
}

\begin{abstract}
Our understanding of the mechanisms of DNA replication in a broad range of organisms and viruses has benefited from the application of two-dimensional agarose gel electrophoresis (2D-AGE). The method resolves DNA molecules on the basis of size and shape and is technically straightforward. 2D-AGE sparked controversy in the field of mitochondria when it revealed replicating molecules with lengthy tracts of RNA, a phenomenon never before reported in nature. More recently, radioisotope labeling of the DNA in the mitochondria has been coupled with 2D-AGE. In its first application, this procedure helped to delineate the "bootlace mechanism of mitochondrial DNA replication," in which processed mitochondrial transcripts are hybridized to the lagging strand template at the replication fork as the leading DNA strand is synthesized. This chapter provides details of the method, how it has been applied to date and concludes with some potential future applications of the technique.
\end{abstract}

Key words DNA replication, DNA labeling, Mitochondrial DNA, Two-dimensional agarose gel electrophoresis, 2D-AGE, Replication intermediates, Humans, Mammals 


\section{Introduction}

The DNA in mitochondria is geared to the production of thirteen polypeptides that are essential for aerobic respiration and ATP pro- duction. Mammalian mitochondrial DNA is typically arranged as closed, circular molecules of $16 \mathrm{~kb}$ pairs. Mitochondrial DNA (mtDNA) is reliant on a host of nuclear-encoded proteins for its maintenance and expression. A plethora of mutations of mtDNA are known causes of human disease, and mutations in the nuclear genes required for its replication can be equally devastating [1-5]. Furthermore mutant mtDNA has been linked to neurodegenerative disorders, in particular Parkinson's disease, and to the normal aging process [6-11]. Hence, greater understanding of the process of mtDNA replication is of considerable importance for many aspects of human health and longevity. The technique of two- dimensional agarose gel electrophoresis (2D-AGE) has under- pinned recent advances in our understanding of the process of DNA replication in mitochondria and combining it with direct DNA labeling expands its range of applications.

\subsection{Neutral Two-Dimensional Agarose Gel Electrophoresis}

The development of a method of separating branched molecules based on a combination of structure and mass transformed the study of DNA replication [12-15]. Neutral 2D-AGE has been used to map origins of replication [13, 15-18], identify replication pause sites and termini $[14,19,20]$, determine the direction of replication fork movement $[19,21,22]$, and define multiple mechanisms of replication [23-28]. The technique is widely applicable, having been used to study DNA replication in eukaryotes, prokaryotes, and viruses [13, 16, 23, 26, 29-35].

The essentials of 2D-AGE are the same irrespective of the source of the DNA. The DNA is usually restriction digested in order to focus on a particular region of the genome of interest, e.g. one suspected to contain a replication origin or pause site. The DNA fragments are first separated in a low percentage agarose gel, at low field strength; in the second dimension, a higher field strength and a higher percentage agarose gel impregnated with the DNA intercalating dye, ethidium bromide, are employed (see Fig. 1 and the step-by-step protocol). It is in the second dimension that the shape of the DNA molecule (specifically its hydrodynamic volume) becomes a key factor: replication intermediates (RIs) migrate slower than linear molecules of the same mass. Hence, the passage of a replication fork through a fragment gives rise to a series of intermediates of different mobility, which form a characteristic fork, or $\mathrm{Y}$, arc (Fig. 2a). If a fragment contains an origin of replication, a bubble structure will form, which is more retarded in the second dimension than a replication fork. When a replication fork exits a fragment the bubble is cleaved by the restriction enzyme (assuming the nascent strands are duplex DNA (see below)), and so bubble arcs end abruptly (Fig. 2b). The extent of a bubble arc depends on the position of the origin within the fragment; how- ever, a single fragment cannot define the mode of replication. Hence, it is necessary to 
analyze a series of overlapping fragments to map origins of replication and determine if replication is unidirectional or bidirectional (Fig. 2c). Such an analysis revealed weak bubble arcs associated with multiple fragments of mammalian and avian mtDNA demonstrating the existence of a broad replication initiation zone in vertebrate mtDNA [22, 36].

Ribonucleotide substitution and RNA incorporation are prominent and highly unusual features of mtDNA metabolism. The mtDNA of mammalian cells and tissues contains sporadic ribonucleotides [37, 38] and lengthy tracts of RNA (transcripts, termed bootlaces) are hybridized to the lagging strand template during replication [38, 39]. Because RNA is much more sensitive to extremes of $\mathrm{pH}$ than DNA, and the RNA/DNA hybrids are prone to enzymatic degradation during nucleic acid isolation, care is required in the preparation of samples for the study of mtDNA replication. All reagents should be tested for contaminating RNase $\mathrm{H}$ activity [40] and sucrose step-gradient purification of the mitochondria is often beneficial. Although in recent years we have produced largely intact RIs from mitochondria of solid tissues prepared solely by differential centrifugation, or even fresh homogenates [41], we are still working toward preparations in which the RNA hybridized to mtDNA is fully intact. This is proving particularly challenging in the case of mtDNA of cultured cells, where even interstrand cross-linking of the mtDNA in intact cells is insufficient to preserve fully the bootlaces [41], and this can explain the recently reported distribution of mtSSB bound to mtDNA in HeLa cell mitochondria [42]. Alternatively, the bootlace mechanism is much sloppier in cultured (aneuploid) cells than in vivo, and missing bootlaces are substituted by $\mathrm{mtSSB}$; but in view of the clear threat to mtDNA integrity posed by extensive single-stranded regions formed during replication [43], we view this as highly unlikely even for cancer cells. Ultimately, quantitative methods that measure the coverage of RNA versus mtSSB on actively replicating molecules will be needed in the future to determine the contributions of each to lagging strand template protection.

Although neutral 2D-AGE is not the only means of dissecting DNA replication, it is one of the few methods appropriate to the study of replicating DNA with a high ribonucleotide content. The alternative form of two-dimensional agarose gel electrophoresis that employs alkali in the second dimension (Neutral/alkaline 2D-AGE) [44] is inapplicable to mammalian mtDNA, because it will result in the fragmentation of the template and nascent DNA strands, as well as complete loss of any RNA/DNA hybrid. In our hands, atomic force microscopy is considerably harsher than 2D-AGE, often leading to fragmentation of mitochondrial replication intermediates (Holt and colleagues, unpublished observations). The formation of RNA/DNA hybrids during mtDNA replication is evident as slow-moving or supra Y arcs (Fig. $2 \mathrm{~d}$ ), as such hybrids are refractive to restriction digestion creating two (or more) contiguous fragments. Once mtDNA samples of high purity have been prepared, RNase $\mathrm{H}$ is a valuable tool for modifying the RIs in vitro $[38,39]$ and incorporated RNA can also be retarded or captured using antibodies specific for RNA/DNA hybrids [40].

\subsection{Combined 2D-AGE and In Organelle Labeling of mtDNA}


A limitation of Southern blots of 2D-AGE is that it shows the steady-state level of replication intermediates. This becomes particularly problematic where there is evidence of multiple mechanisms of replication operating concurrently. If each makes an equal contribution to replication but the rates of DNA synthesis are different then the strongest signal will be contributed by the slowest mechanism. It was also formally possible that many of the RIs detected by 2D-AGE and microscopy methods were dead end products. The solution to this problem is to label the DNA in real-time. DNA labeling in situ can be achieved using a variety of radioactive or fluorescent nucleotide analogs, and these methods lend themselves to pulse-chase analysis. The cells or extracts are incubated with the label for a defined time and its fate can be followed over an extended period. Critical questions are: do the RIs incorporate label rapidly and are they "chased" into mature DNA?

It had been shown in 1994 that mtDNA could be labeled "in organello" by incubating isolated mitochondria with a radioactive deoxynucleotide triphosphate [45]. We discussed the idea of combining 2D-AGE and in organello labeling in the late 1990s, but the standard form of 2DAGE generated such a wealth of data on mtDNA replication in the 2000s that the plan was repeatedly postponed. When eventually tested, the original in organello labeling protocol [45] was found to be robust in our hands and required little in the way of modification.

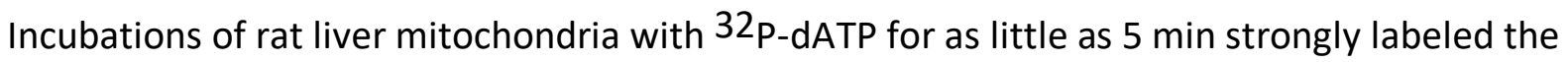
previously assigned RIs, as evidenced by 2D-AGE analysis (Fig. 3), and as with those molecular species detected in the steady-state the supra-Y arcs and most of the material of the bubble arc were grossly modified by RNase $\mathrm{H}$ treatment (Fig. 4) [41]. Moreover, following a fiveminute pulse the signal of the mitochondrial Rls declined with time, whereas that of mature mtDNA accumulated during a chase of up to $2 \mathrm{~h}$, thereby establishing a precursor product relationship between the proposed RIs and mature mtDNA [41]. In our hands, labeling of total mtDNA peaks anywhere between 2 and $3 \mathrm{~h}$ and declines slowly thereafter. Hence it is not possible to extend reactions indefinitely, at least not without further refinement of the protocol.

Our contention that RNA is incorporated on the lagging- strand during the mtDNA replication cycle [38-40] made a firm prediction that could be addressed directly using the in organello labeling system. Radiolabeled RNA precursors should like their dNTP counterparts become incorporated in mitochondrial RIs, but they should not accumulate in the mature mtDNA. ${ }^{1}$ RNA can be labeled in mitochondria in much the same way as DNA labeling [46]. 32P-UTP labeling of mitochondria followed by DNA isola-ion and 2D-AGE revealed a pattern of RIs essentially the same as those detected by DNA labeling [41]. In marked contrast to DNA labeling, incubations of at least an hour with ${ }^{32}$ P-UTP are necessary to be able to detect the mitochondrial RIs, ${ }^{2}$ whereas labeling of the pool of free transcripts is evident within a matter of minutes. A DNA chain terminator inhibits in organelle labeling, whereas a RNA chain terminator has no impact on replication in isolated mitochondria. The delay in RNA labeling of $m t R I s$ and the ineffectiveness of the RNA chain terminator are both incompatible with RNA synthesis on the lagging-strand concurrent with leading-strand DNA synthesis. Instead, the results suggest preformed RNAs are incorporated at the replication fork, with mitochondrial transcripts being the obvious candidates. As predicted by this interpretation, we found it is possible to recover mitochondrial transcripts from gel-extracted mtRIs [41]. 
These studies demonstrate the ability of in organello labeling to address details of the mechanism of mtDNA replication that cannot be achieved by standard 2D-AGE. However, the first study did reveal a possible limitation. While replication intermediates composed of fully duplex DNA are readily detectable by Southern hybridization [22, 36, 40, 47, 48], they were considerably weaker in the material labeled in organello [41]. As described above, this could be taken to imply that coupled leading- and lagging-strand DNA synthesis is slower than the bootlace mechanism of replication. However, the RNA incorporation mechanism is itself very slow, so this explanation seems unlikely. More plausibly, organelle isolation entails disruption of the cell, its cytoskeleton and the mitochondrial network, and so this mechanism of replicaion may not function well outside the cell.

The in organello mtDNA replication system provides a test- bed to study the role of proteins implicated in mtDNA replication and further details of the mechanism(s). Although it will not be easy to source the material, in organello labeling would be ideal to determine if the unusual arrangement of adult heart mtDNA with its innumerable four-way junctions is a replicative, or post-replicative state [49]. Isolated mitochondria retain the capacity to respire and import proteins from the incubation medium and so the levels of individual proteins can be increased during the course of an experiment and the different variants can be assessed in parallel. Recombinant TFAM has already been shown to stimulate 7S DNA synthesis but not increase mtDNA copy number in one study [50]. Testing the DNA helicase Twinkle (C10orf2) is of consider- able interest as it increases mtDNA copy number in the mouse, but not in cultured cells [51, 52]. In addition, for replication factors known, or suspected, to be shared between mitochondria and the nucleus, use of the in organello system allows physiological effects in mitochondria to be studied specifically, which would be considerably more difficult to accomplish in whole cells. The in organello labeling procedure also has the potential to answer many outstand- ing questions about mtDNA replication in pathological states. For example, by studying the relative rate of incorporation of labeled nucleotide precursors into newly synthesized mtDNA, it should be possible to confirm or refute the idea that pathological Twinkle helicase mutants cause replication stalling [51]. Nucleotide balance is also recognized as a critical parameter influencing mtDNA replication, since imbalances precipitate mtDNA depletion and disease [53-55]. This too may lend itself to analysis in organello, although differences in the relative rate of uptake between different nucleotides will need to be taken into account.

\section{Materials}

\subsection{Isolation of Mitochondria from Solid Tissue}

1. Phosphate-buffered saline: $10 \mathrm{mM}$ phosphate buffer, $\mathrm{pH} 7.4,2.7 \mathrm{mM} \mathrm{KCl}, 137 \mathrm{mM} \mathrm{NaCl}$.

2. Homogenization buffer (HB): $320 \mathrm{mM}$ sucrose, $10 \mathrm{mM}$ Tris- $\mathrm{HCl}, \mathrm{pH}$ 7.4, $1 \mathrm{mM}$ EDTA and 1 $\mathrm{mg} / \mathrm{mL}$ essentially fatty acid-free bovine serum albumin (BSA). 
3. Motorized Dounce Homogenizer with tight-fitting Teflon pestle.

4. Sprague-Dawley rats approximately 1 month of age.

5. Refrigerated centrifuge with rotor suitable for pelleting mate- rial at up to $10,000 \times g_{\max }$ in volumes of $10-50 \mathrm{~mL}$.

6. Refrigerated micro-centrifuge.

\subsection{Protein Estimation}

1. UV Spectrophotometer.

2. Sodium dodecyl sulfate (SDS), $0.6 \%(w / v)$. 3. Protein standards.

4. Quartz cuvettes.

\subsection{In Organello Labeling}

1. Rotisserie-style hybridization oven (see Note 1).

2. Incubation buffer (IB): $10 \mathrm{mM}$ Tris- $\mathrm{HCl}, \mathrm{pH} 8.0$, sucrose and glucose $20 \mathrm{mM}$ each, $65 \mathrm{mM}$ d-sorbitol, $100 \mathrm{mM} \mathrm{KCl}, 10 \mathrm{mM} \mathrm{K}_{2} \mathrm{HPO}_{4}, 0.5 \mathrm{mM}$ EDTA, $1 \mathrm{mg} / \mathrm{mL}$ BSA, $1 \mathrm{mM}$ ADP, $5 \mathrm{mM}$ $\mathrm{MgCl}_{2}, 5 \mathrm{mM}$ glutamate, and $5 \mathrm{mM}$ malate (see Note 2).

3. $[\alpha-32 \mathrm{P}]-\mathrm{dATP}(3000 \mathrm{Ci} / \mathrm{mmol})$.

4. $1 \mathrm{mM}$ solutions of dTTP, dGTP, dCTP, and dATP.

5. $[\alpha-32 \mathrm{P}]-U T P(12,000 \mathrm{Ci} / \mathrm{mmol})$.

6. $1 \mathrm{mM}$ solutions of ATP, CTP, and GTP.

\subsection{Mitochondrial DNA Extraction}


1. Lysis buffer (LB): 20 mM HEPES-NaOH, pH 7.8, 75 mM NaCl, 50 mM EDTA.

2. $20 \%(w / v)$ Sodium lauroyl sarcosinate (sarkosyl).

3. Proteinase K (PK): $20 \mathrm{mg} / \mathrm{mL}$ in water.

4.PCIA: equilibrated phenol:chloroform:isoamyl alcohol (25:24:1).

5. CIA: chloroform:isoamyl alcohol (24:1).

6. TE: $10 \mathrm{mM}$ Tris-HCl, pH 8.0, 1 mM EDTA.

7. Isopropanol.

8. Ethanol.

\subsection{Nucleic Acid Restriction and Modification, and 2D-AGE}

1. Restriction enzymes.

2. RNase $T_{1}$, RNase $H$.

3. $5 \mathrm{M} \mathrm{NaCl}$.

4. $10 \mathrm{mM}$ Tris- $\mathrm{HCl}$, pH 8.0.

5. TE: $10 \mathrm{mM}$ Tris-HCl, pH 8.0, 1 mM EDTA.

6. 0.5 M EDTA, pH 8.0.

7. $1 \times$ TBE: $89 \mathrm{mM}$ Tris base, $87 \mathrm{mM}$ boric acid, $2 \mathrm{mM}$ EDTA, $\mathrm{pH}$ 8.0.

8. Loading buffer: $40 \%$ sucrose, $0.025 \%(w / v)$ xylene cyanol \& bromophenol blue.

9. Low electroendosmotic (LEEO) agarose \& ethidium bromide (EB): $10 \mathrm{mg} / \mathrm{mL}$.

10. Gel tank with ports for buffer circulation, peristaltic pump.

11. Power supply \& Ultraviolet (UV) light box.

\subsection{Transfer of mtDNA to Solid Support and Hybridization}


1. Depurination buffer (DPB): $0.25 \mathrm{~N} \mathrm{HCl}$.

2. Denaturing buffer (DNB): $0.5 \mathrm{M} \mathrm{NaOH}, 1.5 \mathrm{M} \mathrm{NaCl}$.

3. Nylon membrane, $3 \mathrm{MM}$ Whatman filter paper \& paper towels.

4. Hybridization buffer: $0.25 \mathrm{M}$ sodium phosphate, $\mathrm{pH} 7.2,7 \%(\mathrm{w} / \mathrm{v})$ SDS.

5. $20 \times$ SSC: $3 \mathrm{M} \mathrm{NaCl}, 0.3 \mathrm{M}$ sodium citrate, $\mathrm{pH} 7.0$.

6. Washing buffer 1 (WB1): $1 \times$ SSC.

7. Washing buffer 2 (WB2): $1 \times$ SSC/0.1\% (w/v) SDS.

8. X-ray film or phosphorimager cassettes.

\section{Methods}

\subsection{Isolation of Mitochondria from Rat Liver}

All solutions should be pre-cooled and all operations carried out on ice in a cold room.

1. First excise and discard the gall bladder, then remove the liver from the rat, separate and discard any associated fat, blood, and blood vessels.

2. Weigh the liver. $4 \mathrm{~g}$ liver provides enough material for $\geq 20$ labeling reactions.

3. Mince the tissue finely with scissors and rinse repeatedly with ice cold 1:10 diluted HB until there is no residual blood or fat.

4. After the final rinse, add $4 \mathrm{~mL} \mathrm{HB} / \mathrm{g}$ minced liver and homogenize using a motorized tight-fitting Dounce homogenizer until the suspension is smooth (see Note 3 ).

5. Centrifuge the homogenate at $1000 \times g_{\max }$ for $5 \mathrm{~min}$ at $4{ }^{\circ} \mathrm{C}$ to pellet nuclei and large debris; repeat this step.

6. Centrifuge the supernatant at $9000 \times g_{\max }$ for $5 \mathrm{~min}$ at $4{ }^{\circ} \mathrm{C}$ to pellet the mitochondria.

7. Discard the supernatant and suspend the mitochondrial pellet in 5 volumes of $\mathrm{HB} / \mathrm{g}$; i.e. $20 \mathrm{~mL}$ for $4 \mathrm{~g}$ of liver (use a loose fitting glass homogenizer to ensure a homogenous solution).

8. Divide the solution among $1.5 \mathrm{~mL}$ or $2 \mathrm{~mL}$ plastic tubes, re- pellet the mitochondria by centrifuging at $10,000 \times g_{\max }$ for $2 \mathrm{~min}$ at $4{ }^{\circ} \mathrm{C}$.

9. Resuspend each pellet in 700 or $800 \mu \mathrm{L}$ of $\mathrm{HB}$ and half the number of tubes; re-pellet the mitochondria by centrifuging at $10,000 \times g_{\max }$ for $2 \mathrm{~min}$ at $4{ }^{\circ} \mathrm{C}$. 
10. Resuspend the mitochondrial pellet in IB and leave to equilibrate for the time taken to estimate the protein concentration.

11. Remove $10 \mu \mathrm{L}$ of mitochondrial suspension and estimate the protein concentration (see Subheading 3.2 below).

12. Pellet the mitochondria $\left(10,000 \times g_{\max }\right.$ for 2 min at $\left.4{ }^{\circ} \mathrm{C}\right)$ and resuspend the organelles in IB at a concentration of $4 \mathrm{mg} / \mathrm{mL}$ protein (see Note 4).

\subsection{Protein Estimation}

1. Mix $1 \mu \mathrm{L}$ of sample with $99 \mu \mathrm{L} 0.6 \%$ SDS in a $0.5 \mathrm{~mL}$ tube.

2. Heat to $95^{\circ} \mathrm{C}$ for $4 \min$.

3. Set the spectrophotometer at $\mathrm{A} 280 \mathrm{~nm}$, add $100 \mu \mathrm{L}$ of $0.6 \%$ SDS to two cuvettes and set the reading as zero.

4. Read the $\mathrm{A} 280 \mathrm{~nm}$ of the sample (from step 1).

5. Calculate the protein concentration based on $0.21 \mathrm{U}$ of Absorbance $=10 \mu \mathrm{g} / \mathrm{mL}$. Thus, A280/0.021 = protein con- centration $\times 10 \mu \mathrm{g} / \mathrm{mL}$ (see Note 5 ).

\subsection{In Organello Labeling of Mitochondrial Nucleic Acid}

1. Prepare $1 \mathrm{~mL}$ lots of mitochondrial suspension in $2 \mathrm{~mL}$ plastic tubes according to the number of reactions required.

2. To each tube add [ $\alpha-32 \mathrm{P}]-\mathrm{dATP}(3000 \mathrm{Ci} / \mathrm{mmol})$ to a final concentration of $6.6 \mathrm{nM}$, and cold dTTP, dGTP and dCTP, each $50 \mu \mathrm{M}$.

3. Incubate at $37^{\circ} \mathrm{C}$ with rotation according to the length of the pulse ( $5 \mathrm{~min}$ to $3 \mathrm{~h}$ ) (see Note 6).

4. If a chase is required pellet the mitochondria, $10,000 \times g_{\max }$ for $2 \mathrm{~min}$ at $4{ }^{\circ} \mathrm{C}$, and resuspend in $1 \mathrm{~mL}$ of IB with all four dNTPs ( $50 \mu \mathrm{M}$ each). Incubate at $37^{\circ} \mathrm{C}$ with rotation accord- ing to the length of the chase.

5. For RNA labeling use $6.6 \mathrm{nM}\left[\alpha^{32} \mathrm{P}\right]$-UTP $(12,000 \mathrm{Ci} / \mathrm{mmol})$, and $50 \mu \mathrm{M}$ each of ATP, CTP, GTP, and the four dNTPs (see Note 7).

\subsection{Mitochondrial DNA Extraction}


1. After the pulse labeling (and chase) reaction, pellet the mitochondria and resuspend them in $475 \mu \mathrm{L} \mathrm{LB}$ (without deter-gent). Add Proteinase K (stock $20 \mathrm{mg} / \mathrm{mL}$ in water) to a final concentration of $0.1 \mathrm{mg} / \mathrm{mL}$ and incubate on ice for $30 \mathrm{~min}$.

2. Add $25 \mu \mathrm{L}$ of $20 \%$ sodium sarkosyl and mix gently.

3. Add an equal volume of PCIA mix gently yet thoroughly.

4. Centrifuge $16,000 \times g_{\max }$ for $5 \min$ at $4^{\circ} \mathrm{C}$.

5. Transfer the upper aqueous phase to a clean tube, mix gently with 1 volume of $\mathrm{CIA}$, and spin at $16,000 \times g_{\max }$ for $5 \min$ at $4{ }^{\circ} \mathrm{C}$.

6. Recover the upper, aqueous phase and add 1 volume of isopropanol and $\mathrm{NaCl}$ to $100 \mathrm{mM}$, mix gently, and incubate at $-20^{\circ} \mathrm{C}$ for $1 \mathrm{~h}$ or overnight.

7. Centrifuge at $20,000 \times g_{\max }$ for $20 \min$ at $4^{\circ} \mathrm{C}$.

8. Wash the pellet with $70 \%$ ethanol and briefly air-dry.

9. Resuspend the pellet in TE, and determine the nucleic acid concentration, e.g. by UV spectrometry.

\subsection{Nucleic Acid Modification and 2D-AGE ( See Note 8)}

1. Digest $3 \mu \mathrm{g}$ lots of total mitochondrial nucleic acid with $10 \mathrm{U}$ of the appropriate restriction endonuclease(s) for $1-3 \mathrm{~h}$ at $37^{\circ} \mathrm{C}$ in a total volume of $200 \mu \mathrm{L}$.

2. To precipitate the digestion products, add $\mathrm{NaCl}$ to $100 \mathrm{mM}$ (maximally $4 \mu \mathrm{L}$ of $5 \mathrm{M} \mathrm{NaCl}$ for a volume of $200 \mu \mathrm{L}), 5 \mu \mathrm{L}$ Glycogen $(10 \mathrm{mg} / \mathrm{mL})$, and 2 volumes of $100 \% \mathrm{EtOH}(420 \mu \mathrm{L})$. Invert the tubes several times. Precipitate at $-20^{\circ} \mathrm{C}$ over- night or $1 \mathrm{~h}$.

3. Centrifuge the sample at $20,000 \times g_{\max }$ for 20 min at $4^{\circ} \mathrm{C}$.

4. Discard the supernatant and wash the pellet with $70 \%$ ethanol.

5. Air-dry the pellet, suspend in TE or in $10 \mathrm{mM}$ Tris- $\mathrm{HCl}, \mathrm{pH} 8.0$ if it is to be treated with modifying reagents. If no additional treatment is required then the sample is ready for 2D-AGE.

6. Our standard conditions for the modifying enzymes used to date are $1 \mathrm{U}$ of RNase $\mathrm{H}$ for 15 min at $37^{\circ} \mathrm{C}$ in $20 \mathrm{mM} \mathrm{HEPES}-\mathrm{KOH}, \mathrm{pH} 7.8,50 \mathrm{mM} \mathrm{KCl}, 10 \mathrm{mM} \mathrm{MgCl} 2,1 \mathrm{mM} \mathrm{DTT} ; 100$ $\mathrm{U}$ of RNase $\mathrm{T}_{1}$ nuclease in $10 \mathrm{mM}$ Tris $-\mathrm{HCl}, \mathrm{pH} 7.4,40 \mathrm{mM} \mathrm{NaCl}, 1 \mathrm{mM} \mathrm{MgCl} 2$ for 15 $\min$ at $37^{\circ} \mathrm{C}$. 
7. Stop the reaction by flash-freezing the sample on dry ice/ ethanol.

8. Prepare a $100 \mathrm{~mL} 0.4 \%$ agarose gel in $1 \times$ TBE buffer and cast in a $110 \times 140 \mathrm{~mm}$ gel tray for 1D-AGE.

9. Submerge gel in a tank containing $1 \times$ TBE.

10. Load samples and appropriate size markers (e.g. kilobase ladder).

11. Run the first dimension at $0.7 \mathrm{~V} / \mathrm{cm}$ for $20 \mathrm{~h}$ at room temperature.

12. After $20 \mathrm{~h}$, cut out the lanes containing the samples with the aid of a razor blade and a ruler.

13. Prepare $400 \mathrm{~mL}$ of $1 \%$ molten agarose gel in $1 \times$ TBE containing $500 \mathrm{ng} / \mathrm{mL}$ EB.

14. Rotate each $1 \mathrm{D}$ gel slice $90^{\circ}$ counter-clockwise and place it in a $200 \times 200 \mathrm{~mm}$ gel-casting tray (see Fig. 1).

15. Remove excess TBE buffer around the gel slice with $3 \mathrm{MM}$ filter paper and adhere the gel slice to the tray with $1 \%$ molten agarose.

16. Cool the $1 \%$ molten agarose to $50{ }^{\circ} \mathrm{C}$ in a water bath and add to the gel tray from the opposite side of the gel slice and wait until it has solidified.

17. Place the gel in a tank containing cold $1 \times$ TBE with $500 \mathrm{ng} / \mathrm{mL}$ EB.

18. Using a peristaltic pump, circulate the buffer from the positive to the negative electrode to avoid the EB accumulating at the cathode.

19. Run the second dimension at $6 \mathrm{~V} / \mathrm{cm}$ for $6 \mathrm{~h}$ at $4{ }^{\circ} \mathrm{C}$.

20. The gel can be dried using a standard gel dryer but the national regulations concerning radioactive condensate must be consulted.

\subsection{Transfer to Solid Support ( See Note 9)}

1. After 2D-AGE, remove the gel from the tank and invert into a glass dish.

2. Add $500 \mathrm{~mL}$ DPB for a dish measuring $300 \times 400 \mathrm{~mm}$, rock gently for $30 \mathrm{~min}$, and discard solution (acid turns xylene cyanol green and BPB yellow).

3. Add $500 \mathrm{~mL}$ DNB and rock gently for $5 \mathrm{~min}$. Pour off the solution and repeat the treatment for 25 min (xylene cyanol and BPB return to their original colors). 
4. Add $500 \mathrm{~mL} \mathrm{NB}$ and rock gently for $10 \mathrm{~min}$. Discard the solution and repeat the treatment for 10-20 min.

5. Cut a piece of nylon membrane to the dimensions of the gel, wet in water and place face down on the gel removing any bubbles with a roller or glass rod.

6. Soak two sheets of $3 \mathrm{MM}$ Whatman filter paper in water and place them on top of the membrane, again avoiding bubbles.

7. Stack $10-12 \mathrm{~cm}$ of paper towel on top of the filter paper.

8. Place a glass plate or a tray on top and a weight to create enough pressure to maintain uniform contact across the gel (see Note 10).

9. Blot overnight on the bench.

10. Remove and discard paper towels and $3 \mathrm{MM}$ Whatman filter paper. Place the membrane face up on $3 \mathrm{MM}$ Whatman filter paper and let stand for a few minutes.

11. Covalently link the DNA to the membrane in a UV cross- linker: total energy $1200 \times 100$ $\mathrm{mJ} / \mathrm{cm}^{2}$.

12. Expose the membrane to an X-ray film or phosphorimager cassette for 30 min to several days.

13. Because of the sensitivity of RNA to extremes of $\mathrm{pH}, \mathrm{DPB}$ and DNB are not appropriate after UTP labeling of mitochondria. Instead the gel should be equilibrated in $6 \times$ SSC buffer, $20 \mathrm{mM} \mathrm{NaOH}$ for $30 \mathrm{~min}$.

14. Rinse the membrane in $6 \times$ SSC, place the gel on a bed of three layers of $3 \mathrm{MM}$ Whatman filter paper soaked in 6× SSC and follow steps 5-12 above.

\subsection{Hybridization to Determine the Steady-State Level of R/s}

1. Place the membrane DNA side up in a hybridization tube and add $15 \mathrm{~mL}$ pre-warmed hybridization buffer at $65^{\circ} \mathrm{C}$.

2. Incubate in a hybridization oven for at least $30 \mathrm{~min}$ at $65^{\circ} \mathrm{C}$.

3. Pour off the solution and repeat the incubation with fresh $15 \mathrm{~mL}$ pre-warmed hybridization buffer at $65^{\circ} \mathrm{C}$.

4. Label a mtDNA-specific probe (see Note 11).

5. Denature the dsDNA probe at $95{ }^{\circ} \mathrm{C}$ for $5 \mathrm{~min}$ and chill on ice for $2 \mathrm{~min}$. 
6. Incubate overnight at $65{ }^{\circ} \mathrm{C}$ for dsDNA probes, $60^{\circ} \mathrm{C}$ for riboprobes and oligonucleotides $>80$ mers. Wash temperatures should also be adjusted down for these last two types of probe. In all cases there should be next to no detectable probe in the wash solution at the end of the process.

7. Discard the hybridization solution containing the probe and wash the membrane four times with $50 \mathrm{~mL} \mathrm{WB1}$ at $65^{\circ} \mathrm{C}$ for $20 \mathrm{~min}$.

8. Wash the membrane twice with $50 \mathrm{~mL} \mathrm{WB2}$ at $65^{\circ} \mathrm{C}$ for $20 \mathrm{~min}$.

9. Remove the membrane from the tube and air-dry briefly.

10. Wrap the membrane in cling film (Saran Wrap). Expose to X-ray film for $0.5-7$ days at -80 ${ }^{\circ} \mathrm{C}$, or to a phosphor cassette.

\section{Notes}

1. Any device that enables the mitochondria to be mixed during the labeling reaction should suffice.

2. Incubation buffer can be stored as a $2 \times$ stock for at least 6 months at $4{ }^{\circ} \mathrm{C}$.

3. Four to six strokes using a IKA Labortechnik RW 20 motorized homogenizer set at speed 5.

4. $40 \mathrm{mg}$ of enriched mitochondria from $4 \mathrm{~g}$ liver is a typical yield providing enough material for 40 reactions.

5. On the first few occasions protein standards should be tested for validation purposes.

6. We adhere the $2 \mathrm{~mL}$ tubes to the outside of a glass hybridization tube using a piece of autoclave tape.

7. Mitochondrial RIs are barely detectable with [ $\alpha-32 \mathrm{P}]$-UTP pulses shorter than $1 \mathrm{~h} ; 2 \mathrm{~h}$ is recommended.

8. The conditions described for 2D-AGE are designed to give optimal resolution of 3-4-kb fragments. In the case of frag- ments of $>5 \mathrm{~kb}, 1 \mathrm{D}$ electrophoresis is in a $0.35 \%$ agarose gel at $1.5 \mathrm{~V} / \mathrm{cm}$ for $20 \mathrm{~h}$, and $2 \mathrm{D}$ at $3 \mathrm{~V} / \mathrm{cm}$ for $18 \mathrm{~h}$ in a $0.875 \%$ agarose gel. For fragments $<3 \mathrm{~kb}$ use $0.9 \mathrm{~V} / \mathrm{cm}$ for $20 \mathrm{~h}$ for $1 \mathrm{D}$ and $0.55-1.0 \%(\mathrm{w} / \mathrm{v})$ agarose, at room temperature (1D) and 2D $9 \mathrm{~h}$ at $260 \mathrm{~mA}, 1.5-2.0 \%$ agarose, at $4{ }^{\circ} \mathrm{C}$.

9. Although capillary transfer to solid support (Southern blot- ting) is not required for in organelle-labeled mtDNA, it is con- venient to transfer the mtDNA fragments to a membrane as drying large radioactive agarose gels is somewhat problematic and subject to strict rules. Moreover, blotting is essential if one wishes to determine the 
relative abundance of actively replicat- ing molecules compared to the steady-state level of RIs (see Subheading 3.7).

10. High pressure does not facilitate capillary transfer, and post- denaturation capillary transfer works well without a reservoir of "transfer" buffer. The efficiency of transfer of in organelle- labeled products can be monitored readily by means of a Gieger counter.

11. Random hexamer-labeled dsDNA probes of cloned or PCR amplified mtDNA can be generated with commercial kits or by assembling the individual reagents. End-labeled oligonucle- otides and riboprobes are both effective ways of gaining strand- specific information.

\section{Acknowledgements}

We thank Drs. Pohjoismäki and Jacobs for the EM image of the replicating mitochondrial DNA molecule, and the Medical Research Council for funding.

\section{References}

1. Holt IJ, Harding AE, Morgan-Hughes JA (1988) Deletions of muscle mitochondrial DNA in patients with mitochondrial myopathies. Nature 331:717-719

2. Spelbrink JN, Li FY, Tiranti V, Nikali K, Yuan QP, Tariq M, Wanrooij S, Garrido N, Comi G, Morandi L, Santoro L, Toscano A, Fabrizi GM, Somer H, Croxen R, Beeson D, Poulton J, Suomalainen A, Jacobs HT, Zeviani M, Larsson C (2001) Human mitochondrial DNA deletions associated with mutations in the gene encoding Twinkle, a phage T7 gene 4like protein localized in mitochondria. Nat Genet 28:223-231

3. Van Goethem G, Dermaut B, Lofgren A, Martin JJ, Van Broeckhoven C (2001) Mutation of POLG is associated with progressive external ophthalmoplegia characterized by mtDNA deletions. Nat Genet 28:211-212

4. Goto Y, Nonaka I, Horai S (1990) A mutation in the tRNA(Leu)(UUR) gene associated with the MELAS subgroup of mitochondrial encephalomyopathies. Nature 348:651-653

5. Shoffner JM, Lott MT, Lezza AM, Seibel P, Ballinger SW, Wallace DC (1990) Myoclonic epilepsy and ragged-red fiber disease (MERRF) is associated with a mitochondrial DNA tRNA(Lys) mutation. Cell 61:931-937

6. Kraytsberg Y, Kudryavtseva E, McKee AC, Geula C, Kowall NW, Khrapko K (2006) Mitochondrial DNA deletions are abundant and cause functional impairment in aged human substantia nigra neurons. Nat Genet 38:518-520

7. Bender A, Krishnan KJ, Morris CM, Taylor GA, Reeve AK, Perry RH, Jaros E, Hersheson JS, Betts J, Klopstock T, Taylor RW, Turnbull DM (2006) High levels of mitochondrial DNA 
deletions in substantia nigra neurons in aging and Parkinson disease. Nat Genet 38:515517

8. Herbst A, Pak JW, McKenzie D, Bua E, Bassiouni M, Aiken JM (2007) Accumulation of mitochondrial DNA deletion mutations in aged muscle fibers: evidence for a causal role in muscle fiber loss. J Gerontol A Biol Sci Med Sci 62:235-245

9. Kowald A, Dawson M, Kirkwood TB (2014) Mitochondrial mutations and ageing: Can mitochondrial deletion mutants accumulate via a size based replication advantage? J Theor Biol 340:111-118

10. Nguyen KV, Sharief FS, Chan SS, Copeland WC, Naviaux RK (2006) Molecular diagnosis of Alpers syndrome. J Hepatol 45:108-116

11. Trifunovic A, Wredenberg A, Falkenberg M, Spelbrink JN, Rovio AT, Bruder CE, Bohlooly YM, Gidlof S, Oldfors A, Wibom R, Tornell J, Jacobs HT, Larsson NG (2004) Premature ageing in mice expressing defective mitochondrial DNA polymerase. Nature 429:417423

12. Bell L, Byers B (1983) Separation of branched from linear DNA by two-dimensional gel electrophoresis. Anal Biochem 130:527-535

13. Brewer BJ, Fangman WL (1987) The localization of replication origins on ARS plasmids in S. cerevisiae. Cell 51:463-471

14. Brewer BJ, Fangman WL (1988) A replication fork barrier at the $3^{\prime}$ end of yeast ribosomal RNA genes. Cell 55:637-643

15. Brewer BJ, Fangman WL (1991) Mapping replication origins in yeast chromosomes. Bioessays 13:317-322

16. Brun C, Dijkwel PA, Little RD, Hamlin JL, Schildkraut CL, Huberman JA (1995) Yeast and mammalian replication intermediates migrate similarly in two-dimensional gels. Chromosoma 104:92-102

17. Dijkwel PA, Vaughn JP, Hamlin JL (1994) Replication initiation sites are distributed widely in the amplified CHO dihydrofolate reductase domain. Nucleic Acids Res 22:4989-4996

18. van Brabant AJ, Hunt SY, Fangman WL, Brewer BJ (1998) Identifying sites of replication initiation in yeast chromosomes: looking for origins in all the right places. Electrophoresis 19:1239-1246

19. Brewer BJ, Lockshon D, Fangman WL (1992) The arrest of replication forks in the rDNA of yeast occurs independently of transcription. Cell 71:267-276

20. Viguera E, Hernandez P, Krimer DB, Boistov AS, Lurz R, Alonso JC, Schvartzman JB (1996) The ColE1 unidirectional origin acts as a polar replication fork pausing site. J Biol Chem 271:22414-22421 
21. Friedman KL, Brewer BJ (1995) Analysis of replication intermediates by two-dimensional agarose gel electrophoresis. Methods Enzymol 262:613-627

22. Reyes A, Yang MY, Bowmaker M, Holt IJ (2005) Bidirectional replication initiates at sites throughout the mitochondrial genome of birds. J Biol Chem 280:3242-3250

23. Belanger KG, Mirzayan C, Kreuzer HE, Alberts BM, Kreuzer KN (1996) Two- dimensional gel analysis of rolling circle replication in the presence and absence of bacteriophage $\mathrm{T4}$ primase. Nucleic Acids Res 24:2166-2175

24. Han Z, Stachow C (1994) Analysis of Schizosaccharomyces pombe mitochondrial DNA replication by two dimensional gel electrophoresis. Chromosoma 103:162-170

25. Kamath S, Leffak M (2001) Multiple sites of replication initiation in the human beta-globin gene locus. Nucleic Acids Res 29:809-817

26. Lunyak VV, Ezrokhi M, Smith HS, Gerbi SA (2002) Developmental changes in the Sciara II/9A initiation zone for DNA replication. Mol Cell Biol 22:8426-8437

27. Preiser PR, Wilson RJ, Moore PW, McCready S, Hajibagheri MA, Blight KJ, Strath M, Williamson DH (1996) Recombination associated with replication of malarial mitochondrial DNA. EMBO J 15:684-693

28. Mesner LD, Li X, Dijkwel PA, Hamlin JL (2003) The dihydrofolate reductase origin of replication does not contain any nonredundant genetic elements required for origin activity. Mol Cell Biol 23:804-814

29. Dijkwel PA, Hamlin JL (1997) Mapping repli- cation origins by neutral/neutral twodimensional gel electrophoresis. Methods 13:235-245

30. Kuzminov A, Schabtach E, Stahl FW (1997) Study of plasmid replication in Escherichia coli with a combination of 2D gel electrophoresis and electron microscopy. J Mol Biol 268:17

31.Linskens MH, Huberman JA (1990) Ambiguities in results obtained with 2D gel replicon mapping techniques. Nucleic Acids Res 18:647-652

32. Little RD, Schildkraut CL (1995) Initiation of latent DNA replication in the Epstein-Barr virus genome can occur at sites other than the genetically defined origin. Mol Cell Biol 15:2893-2903

33. Mayhook AG, Rinaldi AM, Jacobs HT (1992) Replication origins and pause sites in sea urchin mitochondrial DNA. Proc R Soc Lond B Biol Sci 248:85-94

34. Robinson NP (2013) Analysis of branched DNA replication and recombination intermediates from prokaryotic cells by two- dimensional (2D) native-native agarose gel electrophoresis. Methods Mol Biol 1054:45-61 
35.Schvartzman JB, Martinez-Robles ML, Hernandez P (1993) The migration behaviour of DNA replicative intermediates containing an internal bubble analyzed by two-dimensional agarose gel electrophoresis. Nucleic Acids Res 21:5474-5479

36. Bowmaker M, Yang MY, Yasukawa T, Reyes A, Jacobs HT, Huberman JA, Holt IJ (2003) Mammalian mitochondrial DNA replicates bidirectionally from an initiation zone. J Biol Chem 278:50961-50969

37. Grossman LI, Watson R, Vinograd J (1973) The presence of ribonucleotides in mature closed-circular mitochondrial DNA. Proc Natl Acad Sci U S A 70:3339-3343

38. Yang MY, Bowmaker M, Reyes A, Vergani L, Angeli P, Gringeri E, Jacobs HT, Holt IJ (2002) Biased incorporation of ribonucleotides on the mitochondrial L-strand accounts for apparent strand-asymmetric DNA replication. Cell 111:495-505

39. Yasukawa T, Reyes A, Cluett TJ, Yang MY, Bowmaker M, Jacobs HT, Holt IJ (2006) Replication of vertebrate mitochondrial DNA entails transient ribonucleotide incorporation throughout the lagging strand. EMBO J 25:5358-5371

40. Pohjoismaki JL, Holmes JB, Wood SR, Yang MY, Yasukawa T, Reyes A, Bailey LJ, Cluett TJ, Goffart S, Willcox S, Rigby RE, Jackson AP, Spelbrink JN, Griffith JD, Crouch RJ, Jacobs HT, Holt IJ (2010) Mammalian mitochondrial DNA replication intermediates are essentially duplex but contain extensive tracts of RNA/DNA hybrid. J Mol Biol 397:11441155

41. Reyes A, Kazak L, Wood SR, Yasukawa T, Jacobs HT, Holt IJ (2013) Mitochondrial DNA replication proceeds via a "bootlace" mechanism involving the incorporation of processed transcripts. Nucleic Acids Res 41:5837-5850

42. Miralles Fuste J, Shi Y, Wanrooij S, Zhu X, Jemt E, Persson O, Sabouri N, Gustafsson CM, Falkenberg $M$ (2014) In vivo occupancy of mitochondrial single-stranded DNA binding protein supports the strand displacement mode of DNA replication. PLoS Genet 10:e1004832

43. Holt IJ, Jacobs HT (2014) Unique features of DNA replication in mitochondria: a functional and evolutionary perspective. Bioessays 36:1024-1031

44. Huberman JA (1997) Mapping replication origins, pause sites, and termini by neutral/alkaline two-dimensional gel electrophoresis. Methods 13:247-257

45. Enriquez JA, Ramos J, Perez-Martos A, Lopez- Perez MJ, Montoya J (1994) Highly efficient DNA synthesis in isolated mitochondria from rat liver. Nucleic Acids Res 22:1861-1865

46. Cantatore P, Loguercio Polosa P, Mustich A, Petruzzella V, Gadaleta MN (1988) Faithful and highly efficient RNA synthesis in isolated mitochondria from rat liver. Curr Genet 14:477-482 
47. Yasukawa T, Yang MY, Jacobs HT, Holt IJ (2005) A bidirectional origin of replication maps to the major noncoding region of human mitochondrial DNA. Mol Cell 18:651-662

48. Holt IJ, Lorimer HE, Jacobs HT (2000) Coupled leading- and lagging-strand synthesis of mammalian mitochondrial DNA. Cell 100:515-524

49. Pohjoismaki JL, Goffart S, Tyynismaa H, Willcox S, Ide T, Kang D, Suomalainen A, Karhunen PJ, Griffith JD, Holt IJ, Jacobs HT (2009) Human heart mitochondrial DNA is organized in complex catenated networks containing abundant four-way junctions and replication forks. J Biol Chem 284:21446-21457

50. Gensler S, Weber K, Schmitt WE, Perez- Martos A, Enriquez JA, Montoya J, Wiesner RJ (2001) Mechanism of mammalian mitochondrial DNA replication: import of mitochondrial transcription factor $A$ into isolated mitochondria stimulates $7 S$ DNA synthesis. Nucleic Acids Res 29:3657-3663

51.Wanrooij S, Goffart S, Pohjoismaki JL, Yasukawa T, Spelbrink JN (2007) Expression of catalytic mutants of the mtDNA helicase Twinkle and polymerase POLG causes distinct replication stalling phenotypes. Nucleic Acids Res 35:3238-3251

52. Tyynismaa H, Sembongi H, Bokori-Brown M, Granycome C, Ashley N, Poulton J, Jalanko A, Spelbrink JN, Holt IJ, Suomalainen A (2004) Twinkle helicase is essential for mtDNA maintenance and regulates mtDNA copy number. Hum Mol Genet 13: 3219-3227

53. Bourdon A, Minai L, Serre V, Jais JP, Sarzi E, Aubert S, Chretien D, de Lonlay P, PaquisFlucklinger V, Arakawa H, Nakamura Y, Munnich A, Rotig A (2007) Mutation of RRM2B, encoding p53-controlled ribonucleotide reductase (p53R2), causes severe mitochondrial DNA depletion. Nat Genet 39:776-780

54. Nishino I, Spinazzola A, Hirano M (1999) Thymidine phosphorylase gene mutations in MNGIE, a human mitochondrial disorder. Science 283:689-692

55. Saada A, Shaag A, Mandel H, Nevo Y, Eriksson S, Elpeleg O (2001) Mutant mitochondrial thymidine kinase in mitochondrial DNA depletion myopathy. Nat Genet 29:342-344 
1a

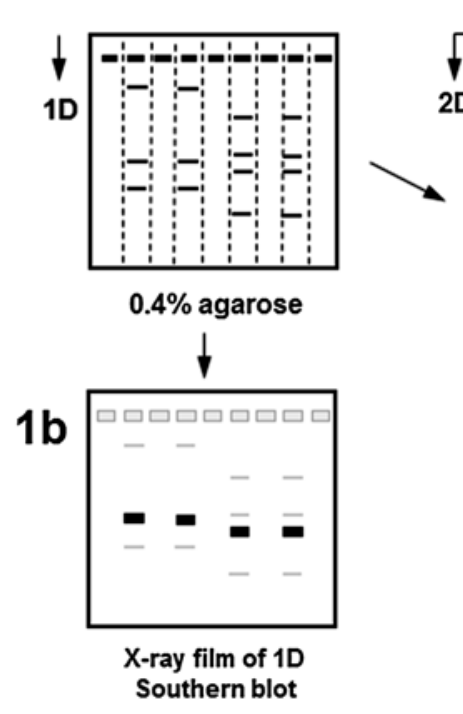

3

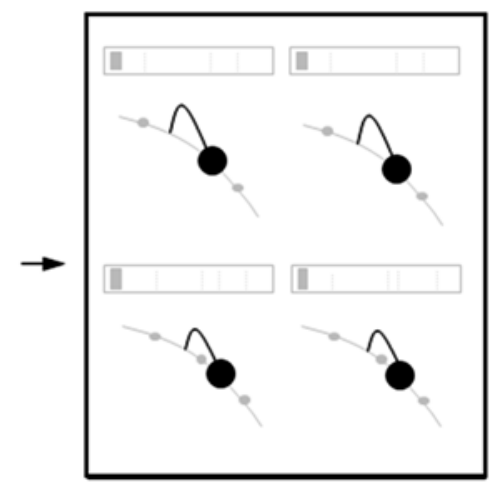

X-ray film of $2 D$ Southern blot

Fig. 1 Schematic diagram of neutral 2D-AGE. Panel 1a depicts a gel after first dimension electrophoresis, filled black boxes represent wells of the gel, narrow horizontal lines are linear fragments of double-stranded DNA, and dotted vertical lines demarcate the lanes to be excised. In a conventional 1D Southern blot (panel $\mathbf{1 b}$ ) the lanes are not excised and specific fragments of DNA are detected after transfer to solid support by hybridization to radiolabeled nucleic acid probes. Panel 2, for 2D-AGE each 1D gel slice is rotated through $90^{\circ}$ and a second gel cast around it, four 1D gel slices are shown on a single 2D gel. After second-dimension electrophoresis the linear double-stranded fragments (black circles) resolve on a defined arc (narrow unbroken line); the position of each fragment after the first dimension separation is shown by a broken faint line in the original 1D gel slice. After blotting and hybridization to detect a specific fragment of (mt)DNA, one of the 1n spots features prominently and its accompanying replication intermediates become visible (panel $\mathbf{3}$ ) 

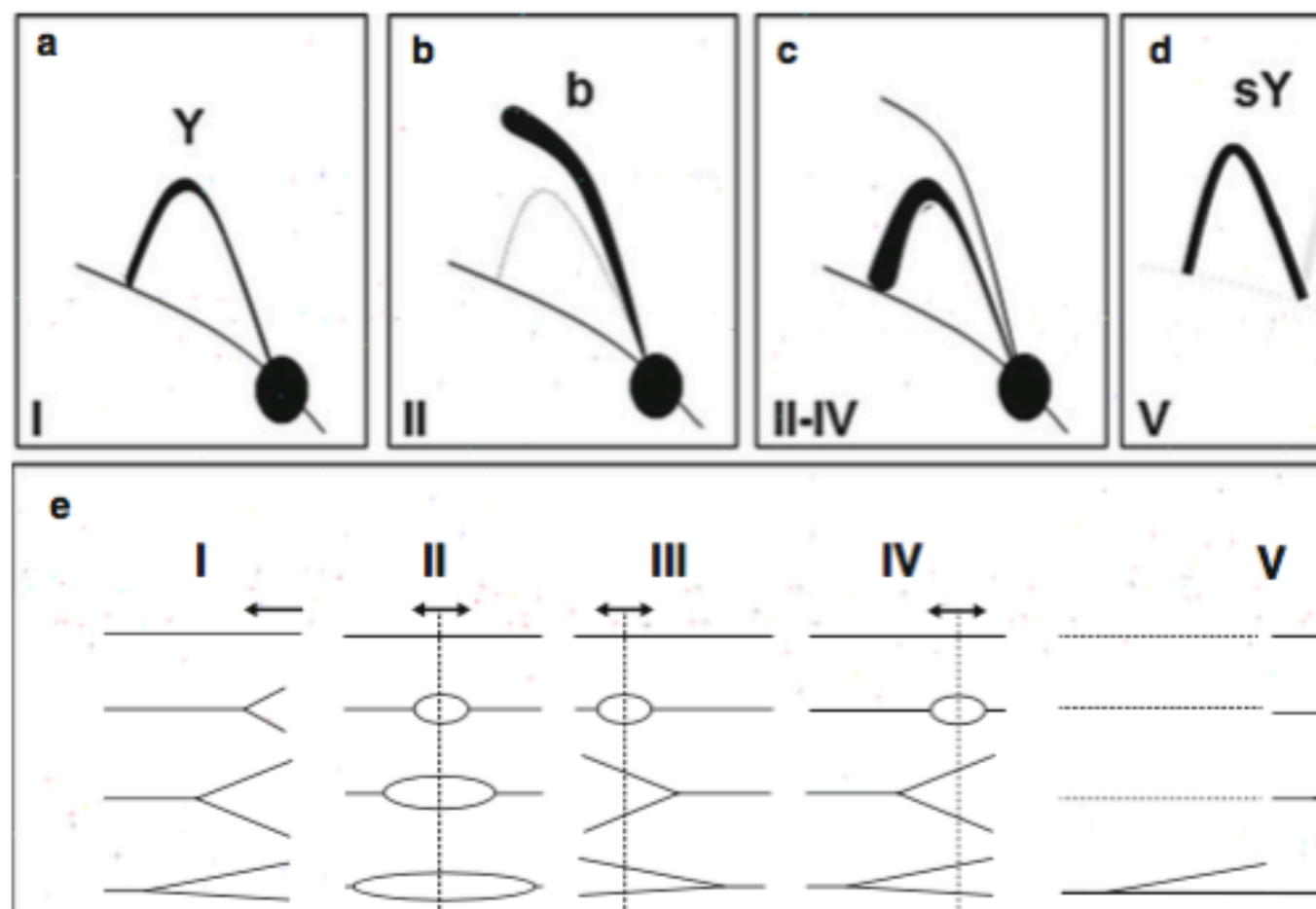

probe
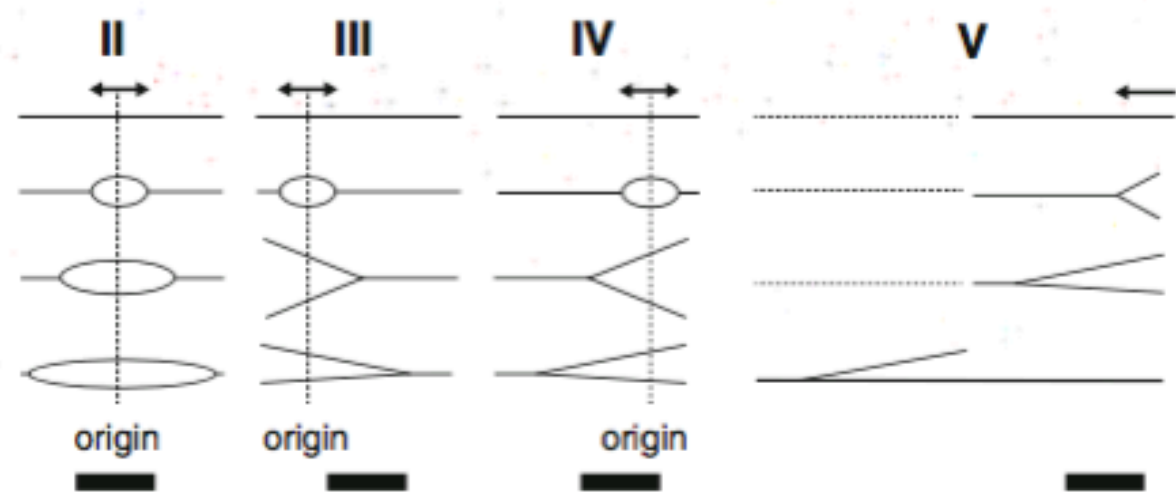

$\rightleftarrows \quad$ Direction of replication

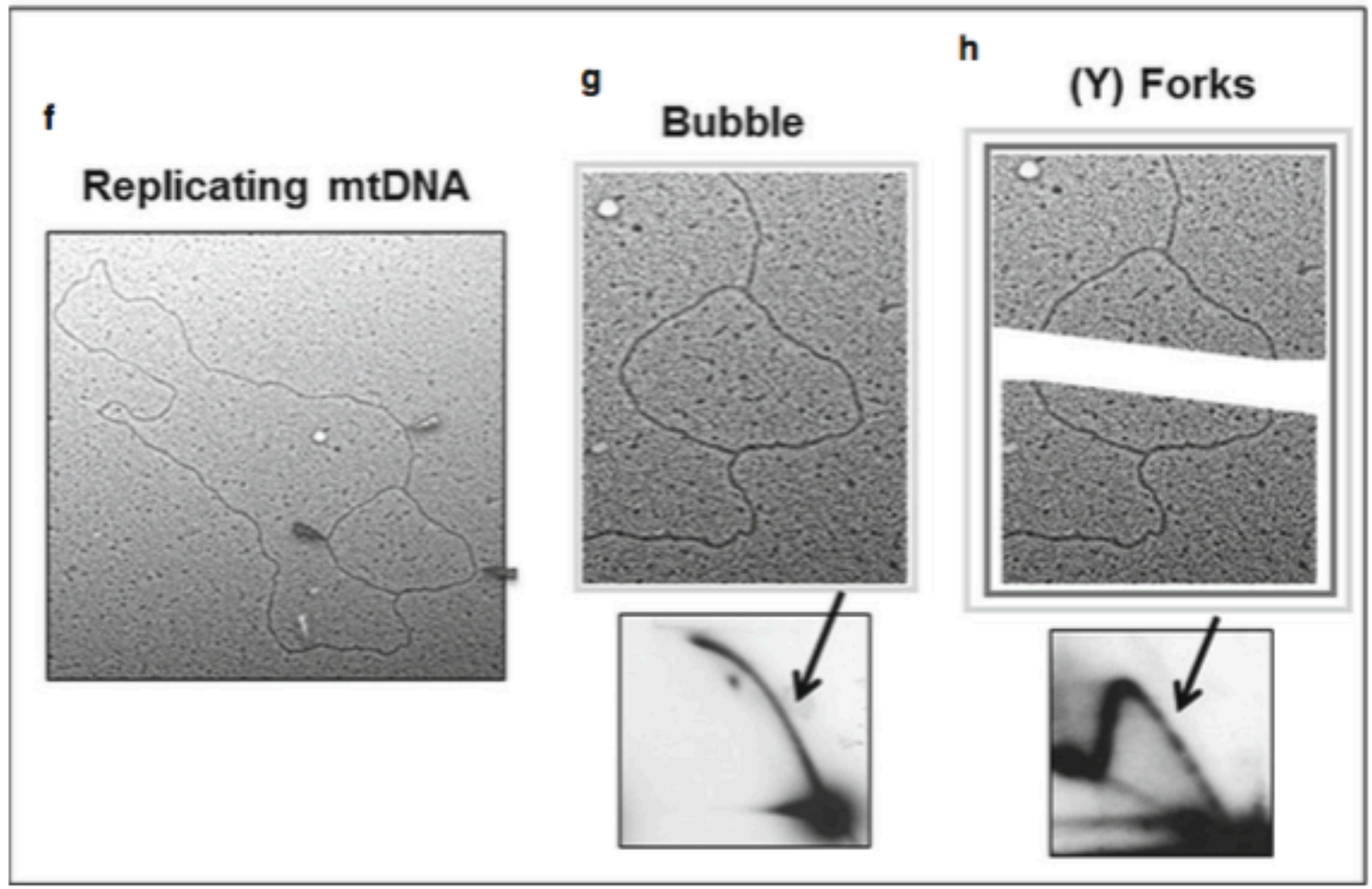


Fig. 2 Interpretations of patterns of replication intermediates fractionated by 2D-AGE. Panels (a-d): schematic patterns of RIs on 2D-AGE. Panel (e), line drawings of structures of RIs. Panel (a), a simple replication fork or $\mathrm{Y}$-arc of duplex DNA, replication initiated outside the fragment, interpreted in e-I. Panel (b), initiation of bidirectional replication from a discrete origin located at the center of a fragment giving rise to a complete bubble arc, because the two forks exit the fragment simultaneously there is no fork arc (the position of the fork arc is shown as a faint broken line for reference purposes). Panel (b) is interpreted in e-II; the bubble arc increases in intensity as it reaches its apex, giving it a "clubheaded" appearance, due to compression. Panel (c), bidirectional initiation from multiple sites across a zone defined by the fragment; in this case initiation at the center of the fragment is only one of many possibilities, at other initiation sites such as those depicted in e-III and e-IV one fork exits the fragment well before the other, converting the bubble to a $Y$ structure. Panel (d), a supra $Y$ (sY) arc of the type associated specifically with mtDNA replication. These result from failure of the restriction enzymes to cut one branch of a RI after the fork has exited a fragment (as depicted in $\mathbf{e}-\mathrm{V}$ ). Panel (f), an electron microscope image of a replicating DNA molecule cut at two light gray restriction sites that preserves the bubble (panel $\mathbf{g}$ ) and a dark gray site located at the center of the bubble (assumed to be a bidirectional origin in this interpretation), cleavage of the bubble converts it to fork structures that con-tribute to the $Y$ arc(s) (panel $h$ ). Note that the image in panel $(\mathbf{g})$ corresponds to one of the points on the arc illustrated in $\mathbf{e}-$ II, whereas $\mathbf{h}$ is equivalent to an $\mathbf{e}-\mathrm{I}$ replication intermediate 


\section{[32P]-dATP labeling}

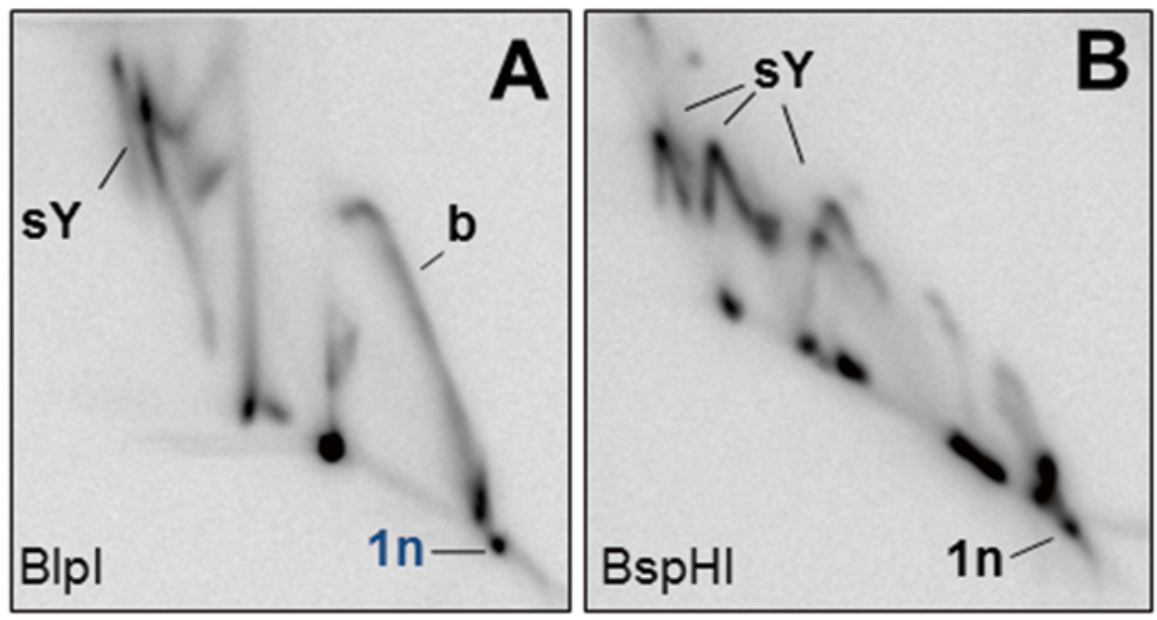

Southern Hybridization

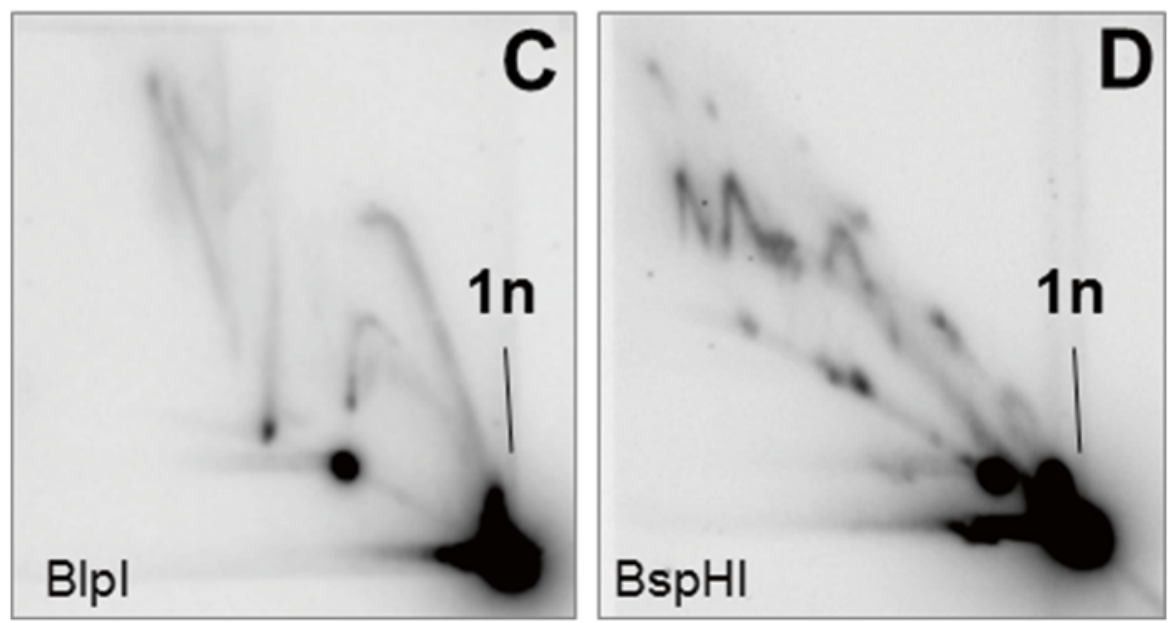

Fig. 3 The majority of mtDNA fragments labeled in organello are replication intermediates. After in organello labeling of rat liver mitochondria, mtDNA was extracted, digested with BIpl or $\mathrm{BspHI}$ and subjected to 2D-AGE. After transfer to solid support, phosphorimager analysis of the Blpl-digested material revealed a prominent bubble arc (b) and a supra-Y (sY) replication fork arc (panels $\mathbf{a}$ and $\mathbf{b}$ ), substantially the same as those detected by Southern hybridization after probing with a radiolabeled probe (panels $\mathbf{c}$ and $\mathbf{d}$ ). Note that the probe detects a specific fragment of mature mtDNA of $5 \mathrm{~kb}(1 \mathrm{n})$, whereas incubation of mitochondria with $\left[\alpha^{32} \mathrm{P}\right]-\mathrm{dATP}$ labels all fragments of the mtDNA during the reaction. The linear fragments of mtDNA cut at all the restriction sites (1n spots) have always been presumed to be non-replicating mtDNA and this is confirmed by the in organello labeling method as their contribution to total signal is many fold lower than the steady-state amount indicated by Southern blotting (panels $\mathbf{a}$ and $\mathbf{b}$ compared with $\mathbf{c}$ and $\mathbf{d}$ ) 


\section{Blpl digested rat liver mtDNA}
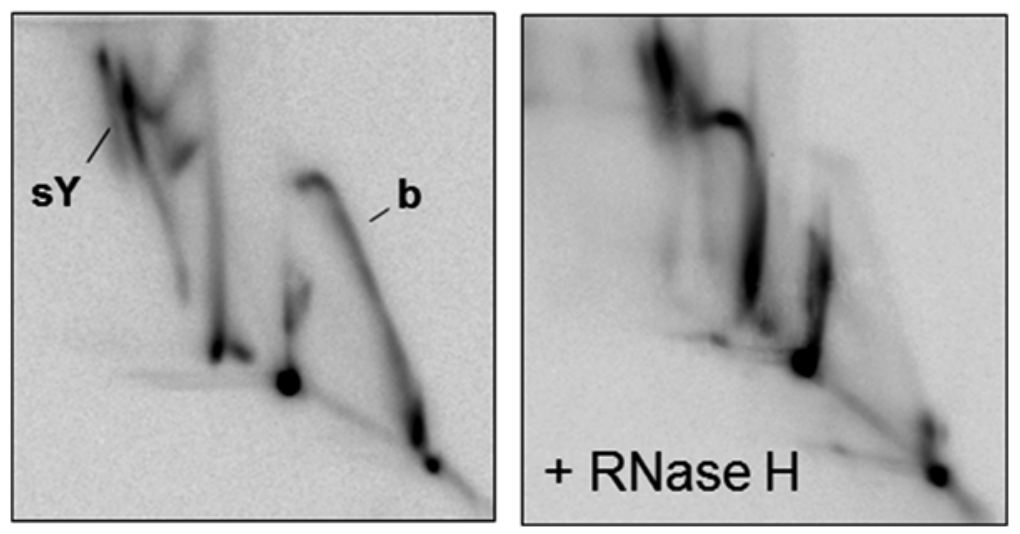

Fig. 4 The majority of mtDNA fragments labeled in organello contain extensive RNA/DNA hybrid. In organello labeled rat liver mtDNA was digested with Blpl, treated with or without RNase $\mathrm{H}$ and the products fractionated by 2D-AGE, transferred to filter-membrane and phosphorimaged. The gross modification of the major arcs (origin-containing bubble (b) arc and supra-Y (sY) arc) indicates that the replication occurring in the mitochondria was predominantly of the bootlace type during the 5 min labeling reaction (see [41]) 